\title{
Tingkat Pengetahuan dan Sikap Ibu tentang Pencegahan Covid-19 pada Balita di Praktik Bidan Mandiri Romauli Medan Marelan Tahun 2021
}

\begin{abstract}
Penulis:
Abstrak:

Ariyanti Gori

Latar Belakang: Covid-19 merupakan penyakit menular yang disebabkan Afiliasi:
STIKes Santa Elisabeth, oleh sindrom pernapasan akut coronavirus 2. Gejala pada anak yang terkonfirmasi Covid-19 muncul gejala yaitu hidung tersumbat, demam, batuk kering nyeri tenggorokan, nyeri dada, nyeri perut, muntah, mual, dan Medan, Indonesia diare. Klasifikasi berdasarkan usia pada anak yang menderita covid-19 adalah 5,8\% berusia 6-17 tahun dan 2,3\% balita (0-5) tahun. Angka

Korespondensi: goriariyanti@gmail.com

Histori Naskah: kesembuhan untuk balita yaitu 2,3\% dan angka kematiannya 0,9\%. Penelitian bertujuan untuk mengetahui tingkat pengetahuan dan sikap ibu tentang pencegahan covid-19 pada balita di Praktik Bidan Mandiri(PBM) Romauli Tahun 2021.

Diajukan: 99-00-9999

Metode: Metode penelitian adalah survey deskriptif dengan menggunakan teknik sample purposive sampling. Sampel dalam penelitian ini yaitu semua ibu yang memiliki balita yang melakukan kunjungan di PBM Romauli pada bulan April Tahun 2021 sebanyak 30 orang.

Hasil. Hasil penelitian diperoleh bahwa dari 30 orang responden terdapat 28 responden $(93,3 \%)$ yang memiliki pengetahuan yang baik dan 2 responden $(6,7 \%)$ memiliki pengetahuan yang cukup dan sikap ibu tentang pencegahan covid-19 sebesar 96,7. Oleh karena itu, disarankan kepada semua ibu yang memililki balita selalu meningkatkan pengetahuan maupun sikap agar dapat menerapkan tindakan pencegahan covid-19 pada balita dengan baik
\end{abstract}

Kata kunci: Knowledge, Attitude, Prevention of Covid-19, Toddlers

\section{Pendahuluan}

COVID-19 merupakan penyakit menular yang disebabkan oleh sindrom pernapasan akut coronavirus 2 (severe acute respiratory syndrome coronavirus 2 atau SARS-CoV-2). Virus ini merupakan keluarga besar Coronavirus yang dapat menyerang hewan. Ketika menyerang manusia, Corona virus biasanya menyebabkan penyakit infeksi saluran pernafasan, seperti flu, MERS (Middle East Respiratory Syndrome), SARS (Severe Acute Respiratory Syndrome), dan dapat menyebabkan kematian. COVID-19 sendiri merupakan corona virus jenis baru yang ditemukan di Wuhan, Hubei, China pada tahun 2019 (Ilmiyah, 2020; Hui, et al., 2020).

Virus ini dapat berpindah secara langsung melalui percikan batuk, bersin dan nafas dari orang yang terinfeksi yang kemudian terhirup oleh orang yang sehat. Penyebaran virus Corona juga dapat secara tidak langsung yaitu melalui benda-benda yang tercemar virus akibat percikan atau sentuhan tangan orang yang terinfeksi virus ini. Virus tersebut dapat tertinggal dipermukaan benda-benda dan hidup beberapa jam hingga beberapa hari namun virus ini dapat dimusnakan dengan cairan disinfektan. (Kemenkes RI, 2020).

Gejala pada anak yang terkonfirmasi COVID-19 dapat asimptomatik atau muncul gejala yaitu hidung tersumbat, demam, sesak/napas cepat, mialgia atau lesu, rinore, batuk kering dan gejala saluran 
napas atas seperti nyeri tenggorokan, nyeri dada, gejala sistem pencernaan, yaitu rasa tidak nyaman di perut, nyeri perut, muntah, mual, dan diare (Kementrian Kesehatan, 2020).

Dampak dari Covid-19 telah melumpukan aktivitas harian masyarakat. Perlu upaya yang konsisten dan terintegrasi guna memutus mata rantai penyebaran Covid-19, terlebih lagi untuk melindungi kelompok yang berisiko terjangkit seperti lansia, penderita penyakit kronis, perokok dan penghisap vape, kaum pria dan orang bergolongan darah A. Selain itu, batita dan anak pra sekolah juga merupakan kelompok yang berisiko terinfeksi Covid 19. (D.L and J.F, 2014).

Adapun usia batita yaitu 1-3 tahun, sedangkan usia anak pra sekolah adalah 3-5 tahun (D.L and J.F, 2014). Direktur Pencegahan dan Pengendalian Masalah Kesehatan Jiwa dan Napza mengatakan bahwa pada tanggal 19 Juli 2020 sudah ada 7.008 anak Indonesia terinfeksi Covid-19, 8,6\% dirawat, 8,3\% sembuh, dan $1,6 \%$ diantaranya meninggal (Nursanti, 2020). Klasifikasi berdasarkan usia pada anak yang menderita covid-19 adalah 5,8\% berusia 6-17 tahun dan 2,3\% balita (0-5) tahun (Nursanti, 2020). Angka kesembuhan untuk balita yaitu 2,3\% dan angka kematiannya 0,9\%. (Kementrian Kesehatan RI, 2020).

Berdasarkan sumber data dari WHO yang dikutip dari (Satuan Tugas Penanganan COVID-19, 2021) Pada tanggal hingga tanggal 15 Febuari 2021 Total kasus terkonfirmasi COVID-19 gobal per tanggal 26 Januari 2021 adalah 108,579,352 kasus dengan 2,396,408 kematian (CFR 2,2 \%) di 222 Negara Terjangkit dan 187 Transmisi lokal. Sedangkan di indonesia pada tanggal 15 Febuari 2021 jumlah positif yang terpapar covid-19 sebanyak 1.223 .930 orang, mengalami kesembuhan sebanyak 1.032.065 dan meninggal 33.367 orang (CFR 2,7\%).(infeksiemerging.kemkes.go.id)

Di Sumut, Berdasarkan data Gugus Tugas Percepatan Penanganan (GTPP) Covid-19, pada tanggal 21 Febuari 2021 pasien yang terkonfirmasi positif covid-19 berjumlah 11.943 orang, yang mengalami kesembuhan sebanyak 10.205 orang dan meninggal 400 orang dan pasien yang di rawat sebanyak 1338 dan menurut data yang dilansir pada halaman situs resmi Covid.pemkomedan.go.id

Oleh karena itu, Kementerian Kesehatan Republik Indonesia telah menerbitkan Panduan Pelayanan Kesehatan Balita pada Masa Pandemi Covid-19 dalam rangka pencegahan penularan Covid-19 pada balita dan anak pra sekolah. Puskesmas harus menjadi ujung tombak dalam mengidentifikasi keluarga yang memiliki anggota balita dan usia pra sekolah serta memberikan sosialisasi mengenai pencegahan penularan Covid-19, dan tetap memberikan edukasi mengenai cara menjaga kesehatan anak (Kementrian Kesehatan RI, 2020)

Untuk melawan virus corona tindakan utama yang perlu kita lakukan adalah disiplin melaksanakan tindakan pencegahan, seperti rajin cuci tangan menggunakan sabun, menerapkan etika batuk dan menggunakan masker, meningkatkan daya tahan tubuh, menjaga jarak dan hindari kerumunan. Orang tua dituntut untuk bisa menjaga kesehatan anak selama masa pandemic corona ini sehingga anak dalam kondisi yang sehat. Cara yang bisa dilakukan oleh orang tua dalam menjaga kesehatan anak adalah dengan pembiasaan perilaku hidup bersih dan sehat di lingkungan rumah.

Menurut Notoatmojo beberapa hal yang perlu diajarkan pada anak untuk mengembangkan perilaku sehat, yaitu menjaga kebersihan diri maupun kebersihan lingkungan dan menjauhkan hal-hal yang berbahaya untuk kesehatan. Kebersihan lingkungan adalah kebersihan tempat tinggal, tempat kerja atau bermain, dan sarana umum. Terdapat dua cara yang menjadi kunci pengendalian penularan covid-19 yang dapat dilakukan masyarakat adalah menggunakan masker, menjaga jarak dan rajin mencuci tangan dengan sabun. Mencuci tangan dengan sabun mencegah penularan virus Covid-19.

Kandungan sabun terbukti secara klinis mampu membunuh bakteri, virus, dan kuman penyakit. Mencuci tangan dengan sabun adalah langkah dasar yang paling mudah dan aman untuk melindungi diri dari virus dan merupakan anjuran dari WHO. Virus Covid-19 bisa berada di mana saja, menempel di benda- 
benda yang ada di sekitar kita. Cara yang paling efektif untuk mencegah penularan virus tersebut adalah dengan sering mencuci tangan pakai sabun. Membiasakan diri mencuci tangan dengan sabun dan air mengalir ini penting dilakukan. Ini yang akan jadi kunci untuk membunuh, merusak, dan mematikan virus yang mencemari tangan kita.

Manfaat mencuci tangan sendiri dalam Notoatmodjo (2003) adalah untuk membersihkan tangan dari kuman penyakit; serta mencegah penularan penyakit seperti diare, kolera,disentri, typhus, kecacingan, penyakit kulit, Infeksi Saluran Pemapasan Akut (ISPA), Tangan menjadi bersih dan bebas dari kuman Penyuluhan merupakan serangkaian kegiatan komunikasi dengan menggunakan media dalam memberikan bantuan terhadap pengembangan potensi, yaitu fisik, emosi, sosial, sikap dan pengetahuan semaksimal mungkin sebagai upaya untuk meningkatkan atau memelihara kesehatan.

Berdasarkan survey pendahuluan di Praktik Bidan Mandiri Romauli masih terdapat beberapa ibu yang memiliki balita saat melakukan kunjungan ataupun berobat ke klinik tersebut tanpa menggunakan masker dan masih kurangnya kesadaran tentang pencegahan covid-19 pada balita sehingga ibu tersebut kurang memperhatikan pelaksanaan 3M terhadap balita yaitu memakai masker, mencuci tangan dan menjaga jarak. Hal ini disebabkan, penulis berasumsi bahwa pentingnya pengetahuan dan sikap ibu dalam membantu upaya pemerintah dalam memutuskan mata rantai persebaran Covid-19 pada balita.

\section{Metode Penelitian}

Rancangan penelitian yang dilakukan yaitu bersifat deskriptif. Penelitian yang bersifat deskriptif digunakan untuk memaparkan atau menjelaskan tingkat pengetahuan dan sikap ibu tentang pencegahan covid-19 pada balita di PBM Romauli Tahun 2021. Teknik pengambilan sampel pada penelitian ini dilakukan dengan menggunakkan metode purposive sampling, yaitu partisipan yang bersedia ikut dalam penelitian di PBM Romauli Tahun 2021. Sampel dalam penelitian ini yaitu 30 orang ibu yang memiliki balita yang melakukan kunjungan pada bulan april di PBM Romauli pada Tahun 2021.

Instrument penelitian yang digunakan untuk pengumpulan data tentang tingkat pengetahuan dan sikap ibu tentang pencegahan covid-19 pada balita adalah lembar kuesioner. Lembar kuesioner digunakan untuk memperoleh informasi dari responden yang berkaitan dengan variable penelitian yakni tingkat pengetahuan dan sikap ibu pada balita. Lembar observasi digunakan untuk memperoleh informasi dari responden yang berkaitan dengan variable penelitian yakni tingkat pengetahuan dan sikap ibu tentang pencegahan covid-19 pada balita. Instrument penelitian yang digunakan dalam pengumpulan data tingkat pengetahuan dan sikap ibu tentang pencegahan covid-19 pada balita yaitu lembar wawancara.

\section{Hasil dan Pembahasan}

Tabel 5.1 Distribusi Frekuensi Karakteristik Ibu yang Memiliki Balita Berdasarkan Umur, Pendidikan terakhir, Pekerjaan, di Praktik Bidan Mandiri Romauli kecamatan Medan Marelan Tahun 2021.

\begin{tabular}{|l|c|c|}
\hline Karakteristik & f & $\mathbf{( \% )}$ \\
\hline Umur & & \\
\hline$<20$ tahun & 1 & 3,3 \\
$21-35$ tahun & 25 & 83,3 \\
$>35$ tahun & 4 & 13,3 \\
\hline \multicolumn{1}{|c|}{ Total } & 30 & 100 \\
\hline Karakteristik & f & $\mathbf{( \% )}$ \\
\hline Pendidikan terakhir & & \\
\hline
\end{tabular}




\section{Health Caring: Jurnal Ilmiah Kesehatan}

Volume : 1 | Nomor 1 | Januari 2022 |E-ISSN : xxxx-Xxxx |

DOI: doi.org/

\begin{tabular}{|c|c|c|}
\hline SD & 1 & 33,3 \\
\hline SMP & 0 & 0 \\
\hline SMA & 23 & 76,7 \\
\hline DIII & 3 & 10,0 \\
\hline $\mathrm{S} 1$ & 3 & 10,00 \\
\hline Total & 30 & 100,0 \\
\hline Karakteristik & $\mathbf{f}$ & $(\%)$ \\
\hline \multicolumn{3}{|l|}{ Pekerjaan } \\
\hline Tidak bekerja & 26 & 86,7 \\
\hline Wiraswasta & 2 & 6,7 \\
\hline Guru & 2 & 6,7 \\
\hline Total & 30 & 100,0 \\
\hline
\end{tabular}

Berdasarkan karakteristik responden umur, data yang diperoleh dari 30 orang responden menunjukkan bahwa yang berusia 21 -35 tahun berjumlah sebanyak 25 orang (83,3\%), responden dengan usia $>35$ tahun berjumlah sebanyak 4 orang $(13,3)$ dan responden dengan usia $>20$ tahun berjumlah 1 oarang $(3,3 \%)$.

Berdasarkan karakteristik responden pendidikan terakhir, bahwa ibu yang memiliki balita memiliki pendidikan terakhir yaitu SMA dengan jumlah 23 orang $(76,7 \%)$, dan pendidikan terakhir D-III berjumlah 3 orang $(10,0)$, pendidikan terakhir S1 berjumlah 3 orang $(10,0)$ dan pendidikan terakhir SD berjumlah 1 orang $(33,3 \%)$.

Berdasarkan karakteristik responden pekerjaan, terlihat bahwa yang tidak memiliki pekerjaan atau sebagai ibu rumah tangga dengan jumlah 26 orang (86,7\%), pekerjaan sebagai guru berjumlah 2 orang $(6,7 \%)$ dan pekerjaan sebagai wiraswasta berjumlah 2 orang $(6,7 \%)$.

\section{1) Tingkat pengetahuan}

\section{Tabel 5.2 Distribusi Frekuensi Tingkat Pengetahuan Ibu yang Memiliki Balita tentang Pencegahan Covid 19 pada Balita di Praktik Bidan Mandiri Romauli Kecamatan Medan Marelan Tahun 2021}

\begin{tabular}{|c|c|c|}
\hline Tingkat Pengetahuan & f & $(\%)$ \\
\hline Baik & 28 & 93,3 \\
\hline Cukup & 2 & 6,7 \\
\hline Kurang & 0 & 0 \\
\hline Total & 30 & 100,0 \\
\hline
\end{tabular}

Berdasarkan Tabel 5.2 distribusi responden frekuesi tingkat pengetahuan menunjukkan bahwa responden sebanyak 28 orang $(93,3 \%)$ dengan kategori baik dan responden yang tingkat pengetahuannya cukup sebanyak 2 orang $(6,7 \%)$. 


\section{2). Sikap}

\section{Tabel 5.3 Distribusi Frekuensi Sikap Ibu yang Memiliki Balita di Praktik Bidan Mandiri} Romauli Medan Tahun 2021

\begin{tabular}{|c|c|c|}
\hline Sikap & F & $\mathbf{( \% )}$ \\
\hline Positif & 29 & 96,7 \\
Negatif & 1 & 3.3 \\
\hline Total & $\mathbf{3 0}$ & $\mathbf{1 0 0 , 0}$ \\
\hline
\end{tabular}

Berdasarkan tabel 5.3 distribusi frekuensi sikap ibu yang memiliki balita tentang pencegahan covid19 pada balita dengan jumlah 29 orang dengan kategori sikap positif dengan presentase (96,7\%).

Karakteristik Ibu yang Memiliki Balita tentang Pencegahan Covid-19 pada Balita di PBM Romauli Medan Tahun 2021

Berdasarkan karakteristik responden umur, data yang diperoleh dari 30 orang responden menunjukkan bahwa yang berusia 21 -35 tahun berjumlah sebanyak 25 orang (83,3\%), responden dengan usia $>35$ tahun berjumlah sebanyak 4 orang $(13,3)$ dan responden dengan usia $>20$ tahun berjumlah 1 orang $(3,3 \%)$.

Umur mempengaruhi pengetahuan, menurut pendapat Budiman (2013) yang menyatakan bahwa usia mempengaruhi daya tangkap dan pola pikir seseorang. Dengan bertambahnya usia seseorang menyebabkan semakin berkembangnya juga daya tangkap dan pola pikirnya sehingga pengetahuan yang didapat semakin meningkat juga. Namun menurut pendapat cropton,J (1997) dikutip dari penelitian aulia (2013) yang menyatakan bahwa usia produktif merupakan usia dewasa aktif dalam kegiatan sehingga mendukung dalam belajar dan memperoleh informasi, akan tetapi ada umur-umur yang menjelng usia lanjut kemampuan penerimaan atau mengingat suatu pengetahuan itu berkurang.

Menurut asumsi peneliti berdasarkan umur terhadap pencegahan covid-19 pada balita di praktik bidan mandiri romauli, semakin cukup umur maka tingkat kematangan dan pola pikir seseorang semakin meningkat.

Berdasarkan karakteristik responden pendidikan terakhir, bahwa ibu yang memiliki balita memiliki pendidikan terakhir yaitu SMA dengan jumlah 23 orang $(76,7 \%)$, dan pendidikan terakhir D-III berjumlah 3 orang $(10,0)$, pendidikan terakhir S1 berjumlah 3 orang $(10,0)$ dan pendidikan terakhir SD berjumlah 1 orang $(33,3 \%)$.

Sesuai dengan pendapat Notoatmodjo (2014), pendidikan dapat mempengaruhi seseorang termasuk juga sikap seseorang akan pola hidup terutama dalam memotivasi peran serta dalam pembangunan, pada umumnya semakin tinggi pendidikan seseorang makin mudah menerima informasi, Namun perlu ditekankan juga bahwa orang yang berpendidikan rendah tidak selalu memiliki pengetahuan yang rendah. Karena untuk mendapatkan suatu informasi tidak hanya ditempuh melalui pendidikan.

Majunya teknologi sekarang yang menyediakan berbagai macam media massa dan internet membuat seseorang dapat dengan mudah untuk mencari informasi baru. Informasi baru inilah yang dapat mempengaruhi pengetahuan masyarakat tentang inovasi baru dan memberi landasan untuk terbentuknya pengetahuan baru tersebut (Seokidjo Notoadmodjo dalam Ulfa 2017). Pengetahuan sangat erat hubunganya dengan pendidikan sehingga diharapkan semakin tinggi tingkat pendidikan seseorang maka akan semakin baik pula perilakunya dan sikapnya (S. Nasution, dlm Putri 2017). 
Menurut asumsi peneliti bahwasanya teori sesuai dengan hasil penelitian dimana ibu yang memiliki pendidikan terakhir SD bersikap positif dalam pencegahan covid-19 pada balita.

Berdasarkan karakteristik responden pekerjaan, terlihat bahwa yang tidak memiliki pekerjaan atau sebagai ibu rumah tangga dengan jumlah 26 orang (86,7\%), pekerjaan sebagai guru berjumlah 2 orang $(6,7 \%)$ dan pekerjaan sebagai wiraswasta berjumlah 2 orang $(6,7 \%)$. Sesuai dengan pendapat Notoatmodjo (2014), bekerja umumnya merupakan kegitan yang menyita waktu. Bekerja bagi ibu-ibu akan mempunyai pengaruh terhadap kehidupan keluarganya.

Menurut peneliti bahwasanya teori sesuai dengan hasil penelitin di karenakan ibu rumah tangga atau ibu yang tidak bekerja memiliki banyak waktu luang untuk mencari tahu informasi tentang pencegahan covid-19 pada balita.

\section{Tingkat Pengetahuan Ibu tentang Pencegahan Covid-19 pada Balita di PBM Romauli Medan Tahun 2021}

Distribusi responden frekuesi tingkat pengetahuan menunjukkan bahwa responden sebanyak 28 orang $(93,3 \%)$ dengan kategori baik dan responden yang tingkat pengetahuannya cukup sebanyak 2 orang $(6,7 \%)$.

Berdasarkan hasil penelitian Felisitas Charpilova (2020) yang berjudul Hubungan Tingkat Pengetahuan Dengan Perilaku Ibu Tentang Pencegahan Penularan Covid-19 Pada Anak usia 3-6 tahun Di Wilayah Kerja Puskesmas Natal Palingkau Pangkalan Bun di peroleh bahwa terdapat 89 orang dengan kategori baik dengan presentase $93 \%$ dan ibu yang memiliki pengetahuan cukup sebanyak 7 orang dengan presentase $7 \%$. Dari data diatas menunjukkan bahwa ibu memiliki pengetahuan yang baik tentang pencegahan covid-19 pada balita.

Notoatmodjo (2007) menyebutkan bahwa ada beberapa faktor yang dapat mempengaruhi tingkat pengetahuan seseorang, yaitu internal dan eksternal, di dalam faktor internal terdapat 3 hal yaitu motivasi, pendidikan dan persepsi, sedangkan di dalam faktor eksternalnya juga terdapat 3 hal yaitu, sosbud,informasi dan lingkungan, individu dapat memiliki pengetahuan terhadap sesuatu tidak hanya dari edukasi saja, namun manfaat disupport oleh banyak penjelasaan yang beredar dari media yang ada misalnya radio, tv, majalah, surat kabar dan lainnya

Notoatmodjo (2003b) menyatakan bahwa perilaku sebagai bentuk hasil dari pendidikan kesehatan dipengaruhi oleh pengetahuan dan sikap, unsur yang sangat penting dalam bentuk tindakkan seseorang dari pengalaman dan penelitian disebut pengetahuan atau kognitif. Pengetahuan disini merupakan hal yang sangat dalam merubah perilaku dan sikap seseorang, karena semakin paham seseorang dengan suatu penyakit, maka seseorang tersebut mengerti dalam menghadapi bencana atau suatu wabah penyakit. Penelitian tersebut diperkuat oleh arbiol,dkk, bahwa dengan memiliki pengetahuan yang cukup, maka seseorang dapat mengetahui dampak dan gejala dari suatu penyakit, yang membuat orang tersebut lebih mementingkan kesehatannya dengan menerapkan tindakan pencegahan.

Menurut asumsi peneliti, bahwa teori sesuai dengan hasil penelitian dikarenakan ibu yang memiliki balita memiliki pengetahuan yang baik tentang pencegahan covid-19 pada balita.

\section{Sikap Ibu yang Memiliki Balita tentang Pencegahan Covid-19 pada Balita}

Berdasarkan hasil penelitian bahwa responden dengan jumlah 29 orang dengan persentase 96,7 \% dengan kategori sikap positif tentang pencegahan covid-19 pada balita di PBM Romauli.

Hasil ini sejalan dengan penelitian sebelumnya yang dilakukan oleh amari akbar,dkk yang berjudul Hubungan Tingkat Pengetahuan Dan Sikap Terhadap Tindakan Pencegahan Covid-19 dengan hasil 
responden yang bersikap positif sebanyak 111 orang dengan presentase 94,1\% mengatakan bahwa responden memiliki tindakan pencegahan covid-19 yang baik.

Menurut Notoatmodjo (2007), tindakan merupakan bentuk nyata dari suatu sikap, tetapi fasilitas dapat menjadi salah satu factor pendukung atau kondisi yang memungkinkan dalam membuat sikap menjadi suatu perbuatan yang nyata, apabila kondisi seseorang rentan terhadap suatu penyakit, maka barulah ia dapat berupaya dan berusaha untuk mengobati dan mencegah penyakit tersebut.

Ahli Social Pshyology, Newcomb berpendapat bahwa kesiapa seseorang untuk bertindak, bukan merupakan pelaksaan motif tertentu merupakan pengertian sikap,untuk detailnya bahwa respon seseorang terkait suatu hal di tempat tertentu bentuk penjiwaan kepada objek merupakan pengertian dari attitude.

Berdasarkan Data Output yang diperoleh dari penelitian ini dijelaskan bahwa adanya sikap terhadap tindakan pencegahan covid-19 dan diketahui bahwa kategori sikap yang positif dapat membuat seseorang menerapkan tindakan pencegahan covid-19 dengan baik. Oleh karena itu dapat disimpulkan bahwa tindakan pencegahan covid-19 dipengaruhi oleh sikap.

\section{Kesimpulan}

Dari hasi penelitian yang dilakukan dengan jumlah sample 30 orang tentang Tingkat Pengetahuan dan Sikap Ibu tentang Pencegahan Covid-19 pada Balita di Praktik Bidan Mandiri Tahun 2021 dapat disimpulkan bahwa:

1. Data Karakteristik pada penelitian ini mencakup pada umur. Data demografi Ibu yang memiliki balita umur 20-35 tahun berjumlah 25 orang dengan presentase 83,3\%, ibu yang memiliki balita berumur $<35$ tahunberjumlah 4 orang dengan persentase $13,3 \%$, dan ibu yang memiliki balita yang berumur $>20$ tahun berjumlah 1 orang dengan persentase $3,3 \%$.

2. Data Karakteristik pada penelitian ini mencakup pada pendidikan terakhir. Data demografi ibu yang memiliki balita yang pendidikan terakhir SD berjumlah 1 orang dengan persentase 3,3\%, ibu yang memiliki pendidikan terakhir SMA berjumlah 23 orang dengan persentase 76,7 \%, ibu yang memiliki pendidikan terakhir D-III berjumlah 3 orang dengan persentase $10 \%$, dan ibu yang memiliki pendidikan terakhir S1 berjumlah 3 orang dengan persentase $10 \%$

3. Data Karakteristik pada penelitian ini mencakup pada pekerjaan. Data demografi ibu yang memiliki pekerjaan sebagai guru berjumlah 2 orang dengan persentase $6,7 \%$, ibu yang memiliki pekerjaan sebagai wiraswasta berjumlah 2 orang dengan persentase $6,7 \%$ dan ibu yang tidak memiliki pekerjaan atau sebagai ibu rumah tangga sebanyak 26 orang dengan persentase $86,7 \%$.

4. Tingkat Pengetahuan Ibu yang memiliki balita di PBM Romauli Tahun 2021 didapatkan hasil bahwa ibu yang memiliki pengetahuan baik berjumlah 28 orang dengan persentase $93,3 \%$ dan yang berpengetahuan cukup berjumlah 2 orang dengan persentase $6,7 \%$.

5. Sikap Ibu yang memiliki balita di PBM Romauli Tahun 2021 didapatkan hasil bahwa ibu yang memiliki sikap positif berjumlah 29 orang dengan persentase $96,7 \%$.

Maka dapat disimpulkan bahwa secara umum Tingkat Pengetahuan dan Sikap Ibu tentang Pencegahan Covid-19 pada Balita di PBM Romauli Tahun 2021 memiliki pengetahuan yang baik dan sikap yang positif.

\section{Referensi}

Almi.(2020). https://almi.or.id/2020/06/05/analisis- penyebab-masyarakat-tidak- patuh- pada-protokolcovid-19/diakses 28 Juni 2020 
Anhusadar, L., \& Islamiyah, I. (2020). Penerapan Perilaku Hidup Bersih dan Sehat Anak Usia Dini di Tengah Pandemi Covid 19. Jurnal Obsesi: Jurnal Pendidikan AnakUsiaDini,5(1),463.https://doi.org/10.31004/obsesi.v5i1.555

Arikunto, S. 2010. Prosedur Penelitian: Suatu Pendekatan Praktik. Jakarta: Rineka Cipta

Atmojo, J. T., Iswahyuni, S., Rejo, R., Setyorini, C., Puspitasary, K., Ernawati, H., Syujak, A. R., Nugroho, P., Putra, N. S., Nurrochim, N., Wahyudi, W., Setyawan, N., Susanti, R. F., Suwarto, S., Haidar, M., Wahyudi, W., Iswahyudi, A., Tofan, M., Bintoro, W. A.,Mubarok, A. S. (2020). Penggunaan Masker Dalam Pencegahan Dan Penanganan Covid-19: Rasionalitas, Efektivitas, Dan Isu Terkini. Avicenna : Journal of Health Research, 3(2), 84-95. https://doi.org/10.36419/avicenna.v3i2.420

Audri Okta AWD (2019) Hubungan Pengetahuan dan Sikap Terhadap Perilaku Cuci Tangan pada Masyarakat Kelurahan Pegirian, Jurnal Promkes : The Indonesian Journal of Health Promotion And Health Education, vol 7 No, 1 (2019) 1-11 DOI : 10.20473/jpk.V7.11.2019 .1-11

Ayu Kurniawati, K. R. (2020). Sosialisasi Hidup Sehat di Tengah Wabah Virus Corona. Jurnal Pemberdayaan Masyarakat Berkarakter. Vol 3 (1) hal. 58-65

Azwar, S. (2010). Sikap manusia Teori dan Pengukurannya. Yogyakarta : Pustaka Pelajar.

Bloom., B.S. 1984. Human Characterisitc and School Learning. New York: Mc Graw

Creswell, John W. 20s15. Penelitian Kualitatif \& Desain Riset. Yogyakarta : Pustaka Pelajar.

Gannika, Lenny \& Sembiring, E. (2020). Tingkat Pengetahuan dan Perilaku Pencegahan Coronavirus Disease 2019 (COVID-19) Pada Masyarakat Sulawesi Utara Lenny Gannika. NERS: Jurnal Keperawatan, 16(2), 83-89.

Hafandi, Z., \& Ariyanti, R. (2020). Hubungan Pengetahuan tentang Covid-19 dengan Kepatuhan Physical Distancing di Tarakan. Jurnal Kebidanan Mutiara Mahakam, 8(2), 102-111. https://doi.org/10.36998/jkmm.v8i2.102

Indonesia, U. U., Indonesia, U. U., \& Indonesia, U. U. (2020). Jurnal Pengabdian Masyarakat (Kesehatan) Vol. 2 No. 2 Oktober 2020 Universitas Ubudiyah Indonesia. 2(2), 100-104.

Indriyanti, D. (2020). Implementasi Protokol Kesehatan pada Petugas Puskesmas di Masa Pandemi : Studi Kasus Puskesmas Cileungsi Kabupaten Bogor. Jurnal Inovasi Aparatur, 2(2), 235-246.

Kaddi, S. M., Lestari, P., \& Adrian, D. (2020). Komunikasi Keluarga Dalam Pencegahan Coronavirus Disease 2019. Jurnal Ilmu Komunikasi, 18(1), 63. https://doi.org/10.31315/jik.v18i1.3701

Kementrian Kesehatan RI (2020) ‘Panduan Kesehatan Balita Pada Masa Pandemi Covid-19’, pp. 1-60.

Kementrian Kesehatan. (2020). Pedoman COVID REV-4. Pedoman Pencegahan Dan Pengendalian Coronavirus Disease (COVID-19), 1(Revisi ke-4), 1-125.

Liu, L. et al. (2016) 'Use of a knowledgeattitude-behaviour education programme for Chinese adults undergoing maintenance haemodialysis: Randomized controlled trial', The Journal of international medical research. 2016/03/07. SAGE Publications, 44(3), pp. 557-568. doi: 
10.1177/0300060515604980. Notoatmodjo, S. (2010).Ilmu Perilaku Kesehatan, Jakarta : Rineka cipta

Mar'ah, E. M. (2020). Tunaikan Layanan Kesehatan Ibu dan Anak di Masa Pandemi Covid-19. Indonesian Journal of Community Health Nursing (Jurnal Keperawatan Komunitas), 5(2), 23-28. https://ejournal.unair.ac.id/IJCHN/article/viewFile/22449/12335

Maulina, C., Vioito, C., Insani, L. A., Nuranisa, R., Amalina, N. N., \& Musta, S. (2020). Edukasi Perawatan Balita Pada Masa Pandemi Covid-19 Di Kelurahan Gondrong, Tangerang Children' S Care Education in the Covid-s19 Pandemic Time in Gondrong Kelurahan, Tangerang. Jurnal Layanan Masyarakat, 4(2), 434-440.

Musfiroh, M., Setyowati, R., Ada, Y. R., \& Sholahuddin. (2020). Implementasi Delapan Fungsi Keluarga Selama Masa Pandemi Covid-19. Seminar Nasional Pengabdian Kepada Masyarakat UNDIP 2020, 310-314.

Ningrum, N. P. (2020). Melatih Adaptasi Kebiasaan Baru Pada Anak. Seminar Nasional Pengabdian Kepada Masyarakat UNDIP 2020, http://proceedings.undip.ac.id/index.php/semnasppm2019/article/view/235

Notoatmodjo, S. (2010). Promosi Kesehatan dan Perilaku. Rineka Cipta .

Nurlaeli, D. R., \& Nurwanti, N. (2017). Kelekatan (Attachment) Ibu - Anak Di Tengah COVID-19. Journal of Chemical Information and Modeling, 53(9), 1689-1699. file:///C:/Users/User/Downloads/fvm939e.pdf

Nursanti, A. (2020) 7.008 Anak Indonesia Positif Covid-19 Kemenkes: 1,6 persennya Meninggal, Aktivitas Tetaplah di Rumah, PikiranRakyatcom.

Pradana, A. A., Casman, C., \& Nur'aini, N. (2020). Pengaruh Kebijakan Social Distancing pada Wabah COVID-19 terhadap Kelompok Rentan di Indonesia. Jurnal Kebijakan Kesehatan Indonesia: JKKI, 9(2), 61-67. https://jurnal.ugm.ac.id/jkki/article/view/55575

Repository, D., \& Jember, U. (2020). Waspada Covid-19 pada Anak.

Rohani, S., Ana, E. F., Qurniasih, N., Wulandari, E. T., Kumalasari, D., Mayasari, A. T., \& Utami, I. T. (2020). Perkembangan Penelitian Kesehatan Ibu Dan Anak Dalam Masa Pandemi Covid-19. Jurnal Pengabdian Kepada Masyarakat Ungu (ABDI KE UNGU) Universitas Aisyah Pringsewu Journal, 2(2), 85-89.

Rohita, R. (2020). Pengenalan Covid-19 pada Anak Usia Prasekolah: Analisis pada Pelaksanaan Peran Orangtua di Rumah. Jurnal Obsesi: Jurnal Pendidikasn Anak Usia Dini, 5(1), 315. https://doi.org/10.31004/obsesi.v5i1.528

Sinaga, L. R. V., Munthe, S. A., \& Bangun, H. A. (2020). Sosialisasi Perilaku Cuci Tangan Pakai Sabun Di Desa Sawo Sebagai - Bentuk Kepedulian Terhadap Masyarakat Ditengah Mewabahnya Virus Covid-19. Jurnal Abdimas Mutiara, 1(2), 19-28. 
Sulastri, N. M., Maharani, J. F., \& Sarilah, S. (2020). Mendongeng Bersama Anak Sebagai Upaya Pencegahan Covid-19. Jurnal Pengabdian UNDIKMA, 1(1), 34-38. https://doi.org/10.33394/jpu.v1i1.2691

Supariasa, Penilaian Status Gizi, J. B. K. E. (2019). Supariasa, Penilaian Status Gizi, Jakarta: Buku Kedokteran EGC. Supariasa, Penilaian Status Gizi, Jakarta: Buku Kedokteran EGC, 53(9), 16891699.

Syafrida, S. (2020). Bersama Melawan Virus Covid 19 di Indonesia. SALAM: Jurnal Sosial Dan Budaya Syar-I, 7(6). https://doi.org/10.15408/sjsbs.v7i6.15325

Tabi, A. (2020). Problematika Stay At Home Pada Anak Usia Dini Di Tengah Pandemi Covid 19. Jurnal Golden Age, 4(01), 190-200. https://doi.org/10.29408/jga.v4i01.2244

Tanjung, Y., \& Saputra, S. (2020). Pembentukan Lingkungan Tangguh Covid - 19 Berbasis Kelompok Perempuan di Kecamatan Medan Polonia Di Sumatera Utara, data penyebaran untuk Kota Medan dan yang tertinggi dibanding kabupaten / kota lainnya . Data per tanggal 11. Jurnal PemberdayaanMasyarakatBerkarakter,3(2).https://journallitbangrekarta.co.id/index.php/jpmb/art icle/download/382/257

Triawanti, Sanyoto, D. D., Hidayah, N., \& Husairi, A. (2020). Buku Pintar Covid19untukIbu.144.https://repodosen.ulm.ac.id/bitstream/handle/123456789/18026/4. Pintar Covid-19 untuk ibu_edit.pdf?sequence=1\&isAllowed=y

Usman, S., Budi, S., \& Nur Adkhana Sari, D. (2020). Pengetahuan Dan Sikap Mahasiswa Kesehatan Tentang Pencegahan Covid-19 Di Indonesia. / Jurnal Ilmu Keperawatan Dan Kebidanan, 11(2), 410-414. Pengetahuan Dan Sikap Mahasiswa Kesehatan Tentang Pencegahan Covid-19 Di Indonesia

Wahyuseptiana, Y. I. (2020). Pembentukan Konsep Penerimaan Diri pada Anak Usia Dini di Masa Pandemi Covid-19. BUANA GENDER: Jurnal Studi GenderDanAnak,5(2),126136.http://ejournal.iainsurakarta.ac.id/index.php/buanagender/article/view/2814

World Health Organization (2020) Coronavirus Disease 2019-Situation Report 182, WHO. doi: 10.1213/xaa.0000000000001218.

Yanti, N. P. E. D., Nugraha, I. M. A. D. P., Wisnawa, G. A., Agustina, N. P. D., \& Diantari, N. P. A. (2020). Public Knowledge about Covid-19 and Public Behavior During the Covid-19 Pandemic. Jurnal Keperawatan Jiwa, 8(4), 491. https://doi.org/10.26714/jkj.8.4.2020.491-504

Yuniarti Tejasari, m dan purbaningsih, Wida, L. (2020). Bunga Rampai Artikel Penyakit Virus Korona ( COVID-19 ) Editor: Titik Respati. Kopidpedia, 24-35. 